\title{
ZINC AND LEAD IN BOTTOM SEDIMENTS AND AQUATIC PLANTS IN RIVER NAREW
}

\author{
Elżbieta Skorbiłowicz'
}

1 Bialystok Technical University, Wiejska 45A, 15-351 Bialystok, Poland, e-mail: e.skorbilowicz@pb.edu.pl

Received: 2014.08.25

Accepted: 2014.10 .17

Published: 2015.01.02

\begin{abstract}
Aquatic ecosystems are a valuable part of natural environment. The increasing level of pollution in waters transforming biocoenoses and other adverse effects of the impact of toxic substances have contributed to the development of biological monitoring. The aim of the study was to determine the changes in contents of zinc and lead in bottom sediments and roots of aquatic plants: Phragmites australis and Acorus calamus in the river Narew. There were 14 points on the river, from where samples of bottom sediments and plant material were collected. The contents of lead and zinc were determined by means of flame atomic absorption spectrophotometry using Varian device. It was proven that bottom sediments were characterized by low contents of zinc and lead except from two sampling points: in Bondary and Narew. Achieved results of analyzes of plant material showed a slight exceeding in the case of lead. Spatial distribution of zinc and lead contents in examined roots of plants coincided with their contents in bottom sediments, which was also confirmed by statistical analysis. It was proven that aquatic plants had greater tendency for accumulation of metals than bottom sediments.
\end{abstract}

Keywords: river, bottom sediment, aquatic plants, zinc, lead.

\section{INTRODUCTION}

Aquatic ecosystems are a valuable part of natural environment. They influence climate, water retention, maintaining an adequate level of groundwater, create ecological corridors, and furthermore play many socio-economic functions [Sadowska 2012]. The development of civilization, industry, agriculture, and transport, contributes to increased environmental pollution, including aquatic ecosystems [Samecka-Cymerman Kempers 2007, Huin et al. 2010]. Among the toxic components reaching the natural environment, heavy metals are a potential threat to the functioning of ecosystems [Helios-Rybicka 1991, Saygideger Dogan 2005, Skorbiłowicz 2012]. Increasing level of pollution in waters transforming the biocoenoses and other adverse effects of the impact of toxic substances contributed to the development of biological monitoring [Kolada Ciecierska 2008, Zimny 2006]. Monitoring assesses the extent of changes and possible negative effects on the basis of observations made on living organisms. Organisms are the fundamental indicator of all processes running within the aquatic environment [Jankowski, 1994]. For years, macrophytes have been used in bio-indication of aquatic ecosystems. Their structure is adapted for a continuous contact with water. They have an extensive system of absorption of various microelements from the environment, both necessary for life, and harmful ones [Rabajczyk, Jóźwiak 2008]

The aim of the study is to determine changes in the contents of zinc and lead in bottom sediments and roots of aquatic plants: Phragmites australis and Acorus calamus in the river Narew.

\section{MATERIAL AND METHODS}

\section{Area of the study}

The study object - river Narew flows through the north-eastern part of Poland, it has a length of $484 \mathrm{~km}$, out of which $455 \mathrm{~km}$ flows in Poland, 
while the rest flows through the territory of Belarus. Narew river is a right tributary of the Vistula river. It is a typical lowland river, whose catchment covers an area of $75175.2 \mathrm{~km}^{2}$. Hydrological conditions occurring in the Narew river catchment are typical for lowland rivers. The areas, through which the Narew river flows, from natural and ecological point of view, are one of the most valuable in Poland. The most important of them include: Bialowieza National Park, Narew National Park, and Biebrza National Park.

Factories localized in the Narew river catchment area rely mainly on raw materials of agricultural origin: sugar mills, slaughterhouses, dairies, as well as fruit and vegetable processing plants. Among other branches of industry in Podlasie, they are light and wood industry facilities, but agro-food industry is of the dominant importance.

Industrial and municipal wastewater treatment plants functioning in the catchment, in most cases meet the requirements specified in the water-legal permits, however, when assessing the overall quality of the water, the impact of wastewaters from larger towns located within the catchment, is visible [WIOŚ 2012].

Analyzing the area crossed by the Narew river, it may be noted that municipalities are essentially agricultural. Consequence of this is the surface runoff from fields, which include fertilizers and plant protection means (that contain a group of active compounds of arsenic, copper, mercury, zinc, or lead).

\section{Field and laboratory works}

Fourteen points were assigned on the river Narew, where samples of bottom sediments and plant material were collected. They were located in such a way to allow for analysis of changes in water environment quality in the river, taking into account the tributaries and wastewater discharge points. Table 1 shows the location of the measurement points. Environmental sampling took place in summer 2012. Bottom sediments were collected in the coastal zone, where the deposition of suspended material occurs. Several individual surface samples of bottom sediments (from a depth of $10 \mathrm{~cm}$ ) from underneath the water were collected in every selected point. The samples were then dried in air till the "air-dried" and stored until determinations [Lis and Pasieczna 1995]. Prior to chemical analysis, bottom sediment sample was dried at $40{ }^{\circ} \mathrm{C}$ and sieved
Table 1. List of measurement points localized on the Narew river

\begin{tabular}{|c|l|c|}
\hline Point & \multicolumn{1}{|c|}{ Nearest town } & $\begin{array}{c}\text { Kilometer of the } \\
\text { river course }\end{array}$ \\
\hline 1 & Bondary & 431.7 \\
\hline 2 & Narew & 410.0 \\
\hline 3 & Suraz & 355.3 \\
\hline 4 & Zoltki & 302.2 \\
\hline 5 & Lomza & 203.5 \\
\hline 6 & Nowogrod & 181.1 \\
\hline 7 & Ostroleka & 147.0 \\
\hline 8 & Rozan & 117.0 \\
\hline 9 & Gnojno & 78.0 \\
\hline 10 & Pultusk & 63.5 \\
\hline 11 & Lubienica & 58.0 \\
\hline 12 & Wierzbica & 41.0 \\
\hline 13 & Dede & 20.0 \\
\hline 14 & Nowy Dwor Mazowiecki & 3.0 \\
\hline
\end{tabular}

through a nylon $0.2 \mathrm{~mm}$ mesh. Bottom sediments were mineralized using nitric acid with addition of hydrogen peroxide [Salminen et al. 2005] in a closed microwave system CEM Mars-5. An analysis of the granulometric composition of sediments by means of sieve method was also performed, involving the separation of raw airdry sediment samples for granulometric fractions in an appropriate set of sieves (hole size of: 2.0 $\mathrm{mm}, 1.0 \mathrm{~mm}, 0.2 \mathrm{~mm}, 0.1 \mathrm{~mm}, 0.063 \mathrm{~mm}, 0.02$ $\mathrm{mm}$ ) connected to a mechanical shaker. Tests of organic matter were carried out by annealing at a temperature of $550^{\circ} \mathrm{C}$, while the reaction of sediments - potentiometrically in water. Samples of aquatic plants (Phragmites australis and Acorus calamus) were collected from the same area as bottom sediments. Each plant test sample was a combination of at least 5 individual samples. After arrival in the laboratory, harvested plant roots were thoroughly washed with tap water to remove sediments and periphyton and rinsed with distilled water. Then they were dried till the constant weight at $80{ }^{\circ} \mathrm{C}$ [Mazej and Germ 2009]. After drying, samples were homogenized and mineralized in nitric acid with hydrogen peroxide using a microwave system CEM Mars-5. According to Du Laing et al. [2003], the above method is most suitable for determination of heavy metals in Phragmites. The contents of lead and zinc were determined by flame atomic absorption spectrophotometry on a Varian device. 
Results of the content of tested metals were given in relation to air-dry sediments and compared with literature data as well as arithmetic means of these metals contents in bottom sediments for Poland (fraction $<0.2 \mathrm{~mm}$ ) [Lis and Pasieczna 1995] and Europe (fraction $<0.15 \mathrm{~mm}$ ) (Salminen et al. 2005). To assess the extent of sediment contamination by heavy metals, proposed classification of aquatic sediments in Poland based on geochemical criteria (Bojakowska and Sokołowska 1998) and on the basis of threshold values taking into account the harmful effects of pollutants accumulated in sediments to aquatic organisms, was applied [Bojakowska 2001]. The results of zinc and lead contents in common reed (Phragmites australis), and ordinary calamus (Acorus calamus) were based on the dry weight of plants and compared with literature data. In contrast, the physiological standard of metals contents for plants was given according to data presented by Kabata-Pendias, Pendias [1999]. Levels of zinc and lead bio-concentration indicator as a ratio of these metals in examined roots of aquatic plants to their contents in bottom sediments, were calculated.

A licensed version of Statistica 10 software was used for statistical analysis of test results. Arithmetic means, medians, standard deviations, and Spearman correlation coefficients were calculated. The results were also subject to Ward's agglomeration cluster analysis based on the concept of a distance of objects or variables in a multidimensional space.

\section{RESULTS AND DISCUSSION}

Particle size analysis of bottom sediments from the Narew river showed characteristics of loose sand. Only at the measuring point Narew it was found that there was a poor loamy sand. Two fractions showed the largest percentage: 1.0-0.2 $\mathrm{mm}$ (mean $55.75 \pm 22.28 \%$ ) and 0.2-0.1 $\mathrm{mm}$ (mean $25.88 \pm 16.97 \%$ ). Analyzed fractions $0.063-0.02 \mathrm{~mm}$ and $<0.02 \mathrm{~mm}$ were absent at points in Bondary, Suraz, Debe, and Nowy Dwor Mazowiecki (Table 2). The content of organic matter in samples of bottom sediments ranged from $0.05 \%$ to $1.59 \%$. The highest content of organic matter was recorded in samples collected in the towns of Gnojno (1.59\%) and Novgorod $(1.17 \%)$. The lowest content not exceeding $0.3 \%$ was found at the measuring points: Suraz, Lom- za, Rozan, Pultusk, Lubienica, Wierzbica, Debe, and Nowy Dwor Mazowiecki (Table 3). The pH of bottom sediment from the river Narew in most cases was neutral or slightly alkaline in the range of $\mathrm{pH} 7.27$ to 8.10 .

Zinc content in dry mass of bottom sediments changed over a wide range. The lowest value was recorded at point Debe $\left(25.9 \mathrm{mg} \cdot \mathrm{kg}^{-1}\right)$, while the largest in points Bondary $\left(175.8 \mathrm{mg} \cdot \mathrm{kg}^{-1}\right)$ and Narew $\left(127.1 \mathrm{mg} \cdot \mathrm{kg}^{-1}\right)$. At points from Ostroleka to the Nowy Dwor Mazowiecki, there were no specific trends related to zinc content in bottom sediments and its contents were at the level of geochemical background. The amount of lead in bottom sediments varied from $5.9 \mathrm{mg} \cdot \mathrm{kg}^{-1}$ up to $40.5 \mathrm{mg} \cdot \mathrm{kg}^{-1}$. Usually higher contents of this element were observed at two measurement points: Bondary (39.8 mg $\left.\cdot \mathrm{kg}^{-1}\right)$ and Narew (40.5 mg $\mathrm{kg}^{-1}$ ) and four times reduced ones starting from the measurement point in Suraz. The increased content was recorded only in point Wierzbica $\left(19.5 \mathrm{mg} \cdot \mathrm{kg}^{-1}\right)$.

Analyzing the arithmetic mean values of zinc content in bottom sediments in Poland amounting to $247 \mathrm{mg} \cdot \mathrm{kg}^{-1}$ and Europe $120 \mathrm{mg} \cdot \mathrm{kg}^{-1}$, it is clear that significantly lower contents of this element were achieved in the present study (average $55.0 \mathrm{mg} \cdot \mathrm{kg}^{-1}$ ). Bojakowska and Sokołowska [1998] reported that lead content in uncontaminated sediments generally did not exceed $30 \mathrm{mg}$ $\cdot \mathrm{kg}^{-1}$. The pattern of lead variability in bottom sediments substantially coincides with the geochemical background of this element in soils, and the Geochemical Atlas of Poland indicates that the arithmetic mean for lead is $68 \mathrm{mg} \cdot \mathrm{kg}^{-1}$ (Lis and Pasieczna 1995), while for Europe $38.6 \mathrm{mg}$ - $\mathrm{kg}^{-1}$ (Salmin et al. 2005). Considerably lower contents were obtained in this study (average 13.6 $\left.\mathrm{mg} \cdot \mathrm{kg}^{-1}\right)$.

Comparing the contents of analyzed elements in bottom sediments of the Narew river, similar or lower metal concentrations in the sediments from European and Asian rivers, were recorded, which ranged $\left(\mathrm{mg} \cdot \mathrm{kg}^{-1}\right)$ : 15-160 $(\mathrm{Pb})$, and 37303 (Zn) [Demirak et al. 2006, Lin et al. 2008, Skorbiłowicz 2012, 2014].

Within the same measurement points, plant material consisting of reed roots and calamus was collected, in which contents of zinc and lead were also determined. Zinc content at common reed growing in the river Narew ranged from $56.5 \mathrm{mg}$ $\cdot \mathrm{kg}^{-1}$ to $205.2 \mathrm{mg} \cdot \mathrm{kg}^{-1}$. The highest levels were recorded in Bondary $\left(205.2 \mathrm{mg} \cdot \mathrm{kg}^{-1}\right)$ and Narew 
Table 2. Contents of granulometric fractions in bottom sediments of the river Narew

\begin{tabular}{|c|c|c|c|c|c|c|c|c|}
\hline \multirow[t]{2}{*}{ River } & \multirow{2}{*}{\begin{tabular}{|l|}
$\begin{array}{c}\text { Measurement } \\
\text { point }\end{array}$ \\
Bondary \\
\end{tabular}} & \multicolumn{7}{|c|}{ Content of granulometric fraction [\% of weights] } \\
\hline & & $>2 \mathrm{~mm}$ & $2.0-1.0 \mathrm{~mm}$ & $1.0-0.2 \mathrm{~mm}$ & $0.2-0.1 \mathrm{~mm}$ & $0.1-0.063 \mathrm{~mm}$ & $0.063-0.02 \mathrm{~mm}$ & $<0.02 \mathrm{~mm}$ \\
\hline \multirow{13}{*}{ Narew } & Narew & 0.14 & 6.96 & 74.76 & 14.52 & 3.6 & n.w. & n.w. \\
\hline & Suraz & 1.60 & 7.80 & 28.62 & 23.42 & 18.28 & 20.24 & n.w. \\
\hline & Zoltki & n.w. & 2.68 & 59.04 & 32.48 & 5.76 & n.w. & n.w. \\
\hline & Łomza & n.w. & 2.70 & 52.90 & 35.20 & 5.90 & 3.18 & 0.08 \\
\hline & Nowogrod & 1.72 & 5.60 & 56.42 & 26.78 & 7.64 & 1.84 & n.w. \\
\hline & Ostroleka & 3.68 & 8.90 & 30.62 & 19.84 & 34.10 & 1.84 & 1.00 \\
\hline & Rozan & n.w. & 1.02 & 19.04 & 64.94 & 11.64 & 2.86 & 0.44 \\
\hline & Gnojno & 0.18 & 1.32 & 21.00 & 54.84 & 22.48 & 0.14 & n.w \\
\hline & Pultusk & 1.66 & 3.02 & 60.56 & 27.82 & 3.82 & 3.12 & n.w. \\
\hline & Lubienica & 1.70 & 4.36 & 75.98 & 17.00 & 0.74 & 0.16 & n.w. \\
\hline & Wierzbica & 4.38 & 10.38 & 67.10 & 15.54 & 1.90 & 0.70 & n.w. \\
\hline & Dede & 4.20 & 1.19 & 84.56 & 8.32 & 0.44 & 0.08 & n.w. \\
\hline & $\begin{array}{l}\text { Nowy Dwor } \\
\text { Mazowiecki }\end{array}$ & 6.38 & 11.80 & 78.52 & 2.76 & 0.48 & n.w. & n.w \\
\hline \multicolumn{9}{|c|}{ Fundamental statistics } \\
\hline \multicolumn{2}{|l|}{ Minimum } & 0.14 & 1.02 & \begin{tabular}{|l|}
19.04 \\
\end{tabular} & 2.76 & 0.44 & 0.08 & - \\
\hline \multicolumn{2}{|c|}{ Maximum } & 6.38 & 11.80 & 84.56 & 64.94 & 34.10 & 20.24 & - \\
\hline \multicolumn{2}{|c|}{ Arithmetic mean } & 2.59 & 5.12 & 55.75 & 25.88 & 8.53 & 3.41 & - \\
\hline \multicolumn{2}{|c|}{ Median } & 1.72 & 4.19 & 58.80 & 21.63 & 4.79 & 1.84 & - \\
\hline \multicolumn{2}{|c|}{ Standard deviation } & 1.91 & 3.53 & 22.28 & 16.97 & 9.93 & 6.04 & - \\
\hline
\end{tabular}

n.w. - not detected by available method

Table 3. Results of tested indicators in bottom sediments and roots of Phragmites australis and Acorus calamus

\begin{tabular}{|c|c|c|c|c|c|c|c|c|c|c|c|c|c|}
\hline \multirow{3}{*}{ River } & \multirow{3}{*}{$\begin{array}{l}\text { Measurement } \\
\text { point }\end{array}$} & \multicolumn{4}{|c|}{ Bottom sediments } & \multicolumn{4}{|c|}{ Phragmites Australis } & \multicolumn{4}{|c|}{ Acorus calamus } \\
\hline & & \multirow[t]{2}{*}{$\begin{array}{l}\mathrm{pH} \text { in } \\
\text { water }\end{array}$} & \multirow{2}{*}{$\begin{array}{c}\begin{array}{c}\text { Org. } \\
\text { matter }\end{array} \\
\%\end{array}$} & $\mathrm{Zn}$ & $\mathrm{Pb}$ & $\mathrm{Zn}$ & $\mathrm{Pb}$ & \multicolumn{2}{|c|}{$\mathrm{BCF}$} & $\mathrm{Zn}$ & $\mathrm{Pb}$ & \multicolumn{2}{|c|}{$\mathrm{BCF}$} \\
\hline & & & & \multicolumn{2}{|c|}{$\mathrm{mg} \cdot \mathrm{kg}^{-1} \mathrm{DM}$} & \multicolumn{2}{|c|}{$\mathrm{mg} \cdot \mathrm{kg}^{-1} \mathrm{DM}$} & $\mathrm{Zn}$ & $\mathrm{Pb}$ & \multicolumn{2}{|c|}{$\mathrm{mg} \cdot \mathrm{kg}^{-1} \mathrm{DM}$} & $\mathrm{Zn}$ & $\mathrm{Pb}$ \\
\hline \multirow{14}{*}{ Narew } & Bondary & 7.47 & 0.38 & 175.8 & 39.8 & 205.2 & 59.5 & 1.16 & 1.49 & 232.3 & 51.6 & 1.32 & 1.29 \\
\hline & Narew & 7.51 & 0.59 & 127.1 & 40.5 & 151.3 & 34.0 & 1.19 & 0.84 & 147.1 & 45.5 & 1.15 & 1.12 \\
\hline & Suraz & 7.67 & 0.21 & 42.3 & 10.3 & 68.9 & 48.0 & 1.62 & 4.66 & 94.5 & 52.3 & 2.23 & 5.01 \\
\hline & Zoltki & 7.99 & 0.36 & 58.9 & 11.2 & 74.7 & 29.3 & 1.23 & 2.59 & 102.1 & 32.5 & 1.74 & 2.90 \\
\hline & Łomza & 8.11 & 0.19 & 41.2 & 9.5 & 70.3 & 27.1 & 1.76 & 2.85 & 91.3 & 29.3 & 2.21 & 3.08 \\
\hline & Nowogrod & 7.39 & 1.17 & 62.3 & 8.3 & 113.6 & 23.0 & 1.82 & 2.78 & 121.3 & 32.1 & 1.94 & 3.86 \\
\hline & Ostroleka & 7.52 & 0.57 & 43.1 & 7.5 & 65.7 & 40.2 & 1.52 & 5.34 & 84.7 & 16.5 & 1.96 & 2.2 \\
\hline & Rozan & 7.27 & 0.29 & 29.9 & 6.1 & 56.5 & 56.5 & 1.89 & 9.26 & 67.3 & 36.1 & 2.25 & 5.91 \\
\hline & Gnojno & 7.53 & 1.59 & 35.8 & 5.9 & 91.2 & 21.0 & 2.54 & 3.55 & 79.1 & 19.3 & 2.21 & 3.27 \\
\hline & Pultusk & 8.09 & 0.28 & 41.4 & 11.5 & 96.4 & 54.0 & 2.32 & 4.69 & 102.3 & 30.5 & 2.47 & 2.65 \\
\hline & Lubienica & 7.81 & 0.14 & 26.7 & 6.5 & 84.3 & 27.1 & 3.15 & 4.16 & 86.9 & 18.5 & 3.25 & 2.85 \\
\hline & Wierzbica & 7.91 & 0.06 & 27.3 & 19.5 & 65.2 & 46.0 & 2.39 & 2.35 & 76.3 & 54.5 & 2.79 & 2.79 \\
\hline & Dede & 7.99 & 0.05 & 25.9 & 5.9 & 79.1 & 19.5 & 1.12 & 3.31 & 62.1 & 12.0 & 2.39 & 2.03 \\
\hline & $\begin{array}{l}\text { Nowy Dwor } \\
\text { Mazowiecki }\end{array}$ & 7.68 & 0.11 & 33.1 & 7.8 & 91.3 & 18.0 & 2.76 & 2.31 & 67.6 & 15.0 & 2.04 & 1.92 \\
\hline \multicolumn{14}{|c|}{ Fundamental statistics } \\
\hline \multicolumn{2}{|l|}{ Minimum } & 7.27 & 0.05 & 25.9 & 5.9 & 56.5 & 18.0 & 1.12 & 0.84 & 62.1 & 12.0 & 1.15 & 1.12 \\
\hline \multicolumn{2}{|c|}{ Maximum } & 8.11 & 1.59 & 175.8 & 40.5 & 205.2 & 59.5 & 3.15 & 9.26 & 232.3 & 54.5 & 3.25 & 5.91 \\
\hline \multicolumn{2}{|c|}{ Arithmetic mean } & - & 0.43 & 55.0 & 13.6 & 93.8 & 35.9 & 1.89 & 3.58 & 101.2 & 31.9 & 2.14 & 2.92 \\
\hline \multicolumn{2}{|c|}{ Median } & - & 0.29 & 41.3 & 8.9 & 81.7 & 31.6 & 1.79 & 3.08 & 89.1 & 31.6 & 2.21 & 2.82 \\
\hline \multicolumn{2}{|c|}{ Standard deviation } & - & 0.44 & 43.35 & 11.78 & 40.5 & 14.44 & 0.64 & 2.06 & 44.5 & 14.56 & 0.53 & 1.31 \\
\hline
\end{tabular}


$\left(151.3 \mathrm{mg} \cdot \mathrm{kg}^{-1}\right)$, while content of this element in bottom sediments decreased to a value below $100 \mathrm{mg} \cdot \mathrm{kg}^{-1}$ (natural, optimal value according to Kabata-Pendias, Pendias [1999], the point in Nowogrod was the exception (113.6 mg $\left.\cdot \mathrm{kg}^{-1}\right)$. Similar trends were found in calamus. The highest content was recorded in Bondary $(232.2 \mathrm{mg}$ $\cdot \mathrm{kg}^{-1}$ ) and Narew $\left(147.1 \mathrm{mg} \cdot \mathrm{kg}^{-1}\right)$, and a pronounced decrease in the zinc content at sweet flag was visible from the measurement point Ostrole$\mathrm{ka}$, which ranged from $67.3 \mathrm{mg} \cdot \mathrm{kg}^{-1}$ (Rozan) to $102.3 \mathrm{mg} \cdot \mathrm{kg}^{-1}$ (Pultusk). Lower concentrations of zinc in reed occurred in lakes of Suwalki Landscape Park and they ranged from 5.719 to content $27.689 \mathrm{mg} \mathrm{Zn} \cdot \mathrm{kg}^{-1} \mathrm{DM}$ [Dobicki 2004].

The lead content in roots of common reed varied from $18.0 \mathrm{mg} \cdot \mathrm{kg}^{-1}$ to $59.5 \mathrm{mg} \cdot \mathrm{kg}^{-1}$, while in calamus $12.0 \mathrm{mg} \cdot \mathrm{kg}^{-1}$ to $54.5 \mathrm{mg} \cdot \mathrm{kg}^{-1}$ with the greatest amount of this element in the case of common reed in the following towns: Bondary $\left(59.5 \mathrm{mg} \cdot \mathrm{kg}^{-1}\right)$, Rozan $\left(56.5 \mathrm{mg} \cdot \mathrm{kg}^{-1}\right)$, and Pultusk $\left(54.0 \mathrm{mg} \cdot \mathrm{kg}^{-1}\right)$. Sweet flag accumulated the largest quantities of lead at the following measurement points: Wierzbica $\left(54.5 \mathrm{mg} \cdot \mathrm{kg}^{-1}\right)$, Suraz $\left(52.3 \mathrm{mg} \cdot \mathrm{kg}^{-1}\right)$, and Bondary $\left(51.6 \mathrm{mg} \cdot \mathrm{kg}^{-1}\right)$. Kabata-Pendias and Pendias [1999] indicated the excessive amounts at levels ranging $30-300 \mathrm{mg} \mathrm{Pb}$ $\cdot \mathrm{kg}^{-1} \mathrm{DM}$. None of the analyzed samples showed the exceeding the maximum value of $300 \mathrm{mg}$. $\mathrm{kg}^{-1}$, whereas the value $30 \mathrm{mg} \cdot \mathrm{kg}^{-1}$ was exceeded by about $50 \%$ of samples tested. Significantly lower values of $\mathrm{Pb}$ were recorded in the upper Narew river and its tributaries in 2002-2007. Average contents of this element in roots of reeds and calamus did not exceed $15 \mathrm{mg} \cdot \mathrm{kg}^{-1} \mathrm{DM}$ [Skorbiłowicz 2012].

To estimate the size of the impurities in the trophic chains, the bio-concentration factor (BCF) is defined, which uses information about the concentrations of substances in an organism and the outside environment. A high bio-concentration factor can prove the increased bioavailability of a given substance for a particular organism. Aquatic organisms living in contaminated environment easily absorb toxic substances, even in small concentrations [Sadowska 2012]. The highest bioaccumulation appears to be for heavy metals due to their slow metabolism in an organism [Lamdrum et al. 1996]. Bio-concentration factor for zinc in common reed reached the mean value of $1.89 \pm 0.64$ and in $80 \%$ it ranged from 1.1 to 2.4 . Its highest values were reported at measurement points: Gnojno (2.54), Nowy Dwor Mazowiecki
(2.76), and Lubienica (3.15). A similar range of BCF values occurred in the calamus: also $80 \%$ of the results ranged within 1.1-2.4 at slightly higher mean value of $2.14 \pm 0.53$. Also, the largest accumulation of zinc in calamus occurred in Lubienica (3.25). The test plants showed higher bio-concentration factor for lead at a large diversity of results with an average of: reed $-3.58 \pm$ 2.06 , sweet flag $-2.92 \pm 1.31$. It was shown that lead was the most accumulated in the common reed in Rozan (9.26), while calamus at the point in Suraz (5.01).

The results allow to conclude that at the measurement points Bondary and Narew, the accumulation conditions for elevated zinc and lead amounts occurred in bottom sediments and roots of plants. The metal contents at these points were two-three times higher than at neighboring points. This may be an effect of supply of unspecified substances from the area of Belarus to the river Narew waters. Siemianowka reservoir may also have large impact on the quality of river at the point Bondary. Algal blooms are frequent in the reservoir. The bottom of a shallow reservoir with a long water exchange time consists of marshland peat soils. However, in the Narew village, cleaned and treated household and industrial wastewater, as well as storm water, including agriculturaltype pollution, are discharged into the river. Considering the zinc and lead concentration in bottom sediments and plants along the entire length of the river, a downward trend is visible (Figures 1-6).

The test material, in the form of numerical contents, was subject to statistical analysis. The analyzes showed a significant statistical correlation of zinc content in bottom sediments vs. its quantity in the roots of sweet flag $(\mathrm{r}=0.86)$, organic matter $(\mathrm{r}$ $=0.72$ ), and granulometric factions $0.1-0.063 \mathrm{~mm}$ $(\mathrm{r}=0.56)$ and $0.063-0.02 \mathrm{~mm}(\mathrm{r}=0.70)$. It was also statistically confirmed that zinc content in the roots of Acorus calamus depends on the amount of organic matter in the sediment $(\mathrm{r}=0.54)$, and zinc content in Phragmites australis $(\mathrm{r}=0.64)$. Also significant correlations between the content of $\mathrm{Pb}$ in sediments vs. its content in the roots of Acorus calamus $(\mathrm{r}=0.71)$ were found. There were positive correlations between the content of organic matter in bottom sediment and the percentage of two granulometric fractions $0.1-0.063 \mathrm{~mm}(\mathrm{r}=$ $0.69)$ and $0.063-0.020(\mathrm{r}=0.70)($ Table 4$)$.

During the analysis of the data obtained, Ward cluster analysis (CA) was carried out in relation to the variation of zinc and lead contents in bottom 


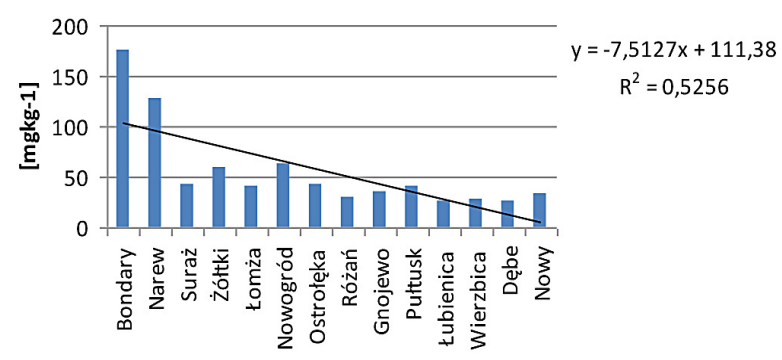

Figure 1. Zinc content in bottom sediments from the river Narew

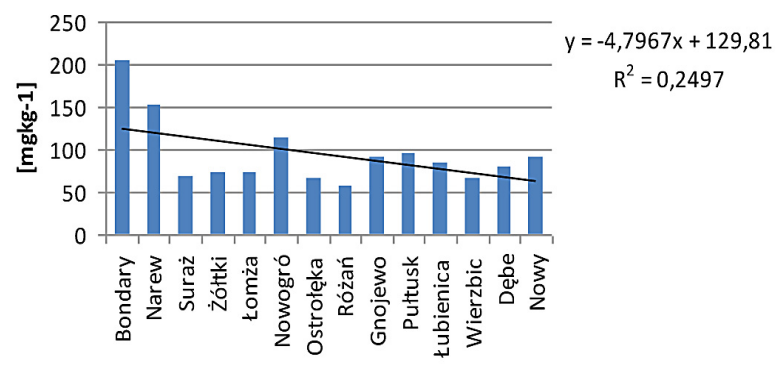

Figure 2. Zinc content in calamus from the river Narew

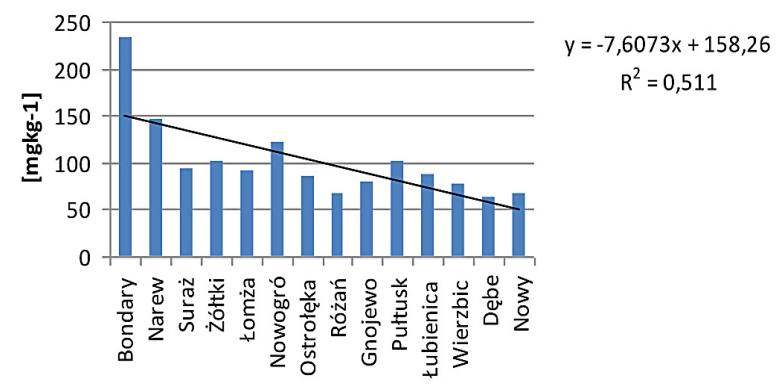

Figure 3. Zinc content in reed from the river Narew

Table 4. Dependencies between zinc and lead contents in bottom sediments and plant roots vs. factors determining their concentrations $(\mathrm{p}<0.05)$

\begin{tabular}{|l|c|}
\hline \multicolumn{1}{|c|}{ Dependencies } & Spearman coefficient \\
\hline $\mathrm{Zn}^{\circ}-\mathrm{Zn}^{\text {Tat }}$ & 0.86 \\
$\mathrm{~Pb}^{\circ}-\mathrm{Pb}^{\text {Tat }}$ & 0.71 \\
$\mathrm{Zn}^{\circ}-$ sub. org. & 0.72 \\
$\mathrm{Zn}^{\circ}-\mathrm{F}^{0,1-0,063}$ & 0.56 \\
$\mathrm{Zn}^{\circ}-\mathrm{F}^{0,063-0,02}$ & 0.70 \\
$\mathrm{Zn}^{\text {Tat }}-\mathrm{Zn}^{\top \mathrm{rz}}$ & 0.63 \\
$\mathrm{Zn}^{\text {Tat }}-$ sub. org & 0.54 \\
$Z \mathrm{n}^{\top \mathrm{rz}}-\mathrm{F}^{2,0-1,0}$ & 0.71 \\
Sub. org $-\mathrm{F}^{0,1-0,063}$ & 0.69 \\
Sub. org $-\mathrm{F}^{0,063-0,02}$ & 0.70 \\
\hline
\end{tabular}

Comments: ${ }^{\circ}$ - bottom sediments; ${ }^{\text {Tat }}$ - calamus; Trz - reed; F - granulometric fractions.

Sub. org organic matter

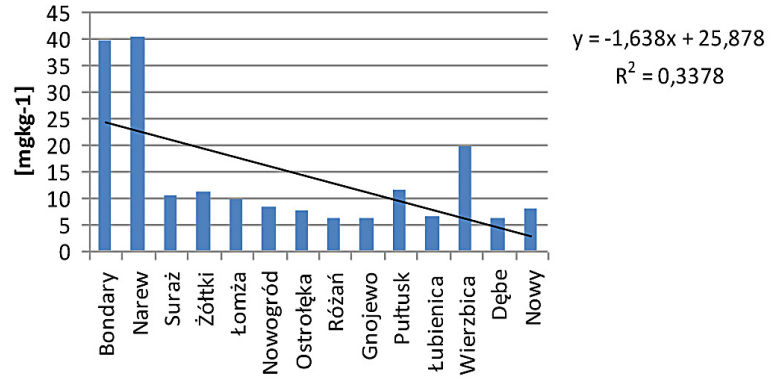

Figure 4. Lead content in bottom sediments from the river Narew

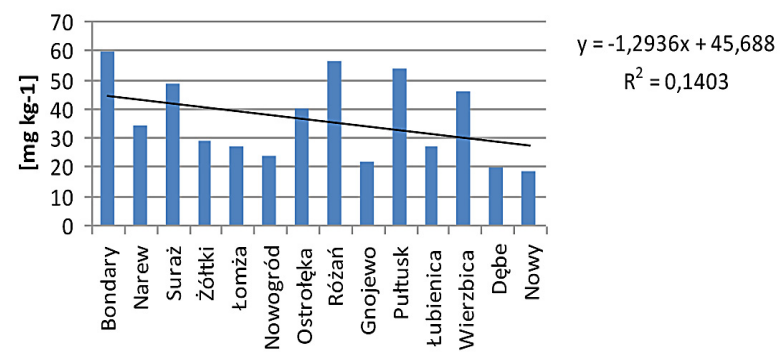

Figure 5. Lead content in calamus from the river Narew

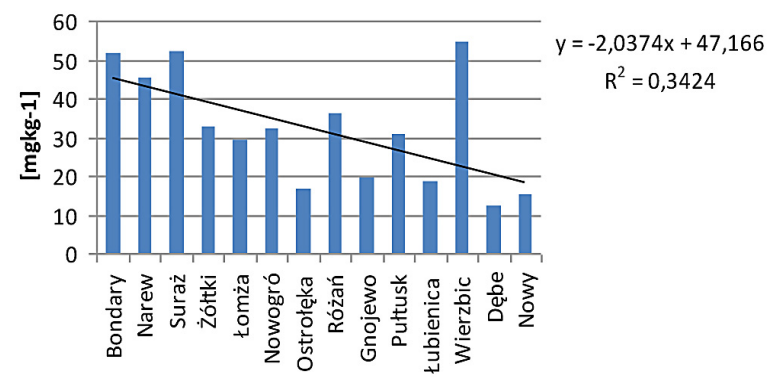

Figure 6. Lead content in reed from the river Narew

sediments and roots of reed and calamus, as well as the tested grain size of sediments, $\mathrm{pH}$ of sediments and organic matter. The Ward model consists of two main groups and four subgroups. The analysis of the first main group showed that lead content in reed and calamus roots was associated with the fraction of $1.0-0.2 \mathrm{~mm}$, the amount of which was the highest in studied sediment - about $56 \%$ of weights. Besides the first major group, the diagram also illustrates the relationship of zinc content in reeds and calamus vs. its amount in bottom sediments. The second cluster indicates that the accumulation of lead in sediments is mainly connected with the fraction of $0.1-0.063 \mathrm{~mm}$ and $0.2-0.1 \mathrm{~mm}$ (together about $65 \%$ of weights), as well as with organic matter, $\mathrm{pH}$, and fractions 2.0 $1.0 \mathrm{~mm}$ and $0.063-0.02 \mathrm{~mm}$ (Figure 7). 


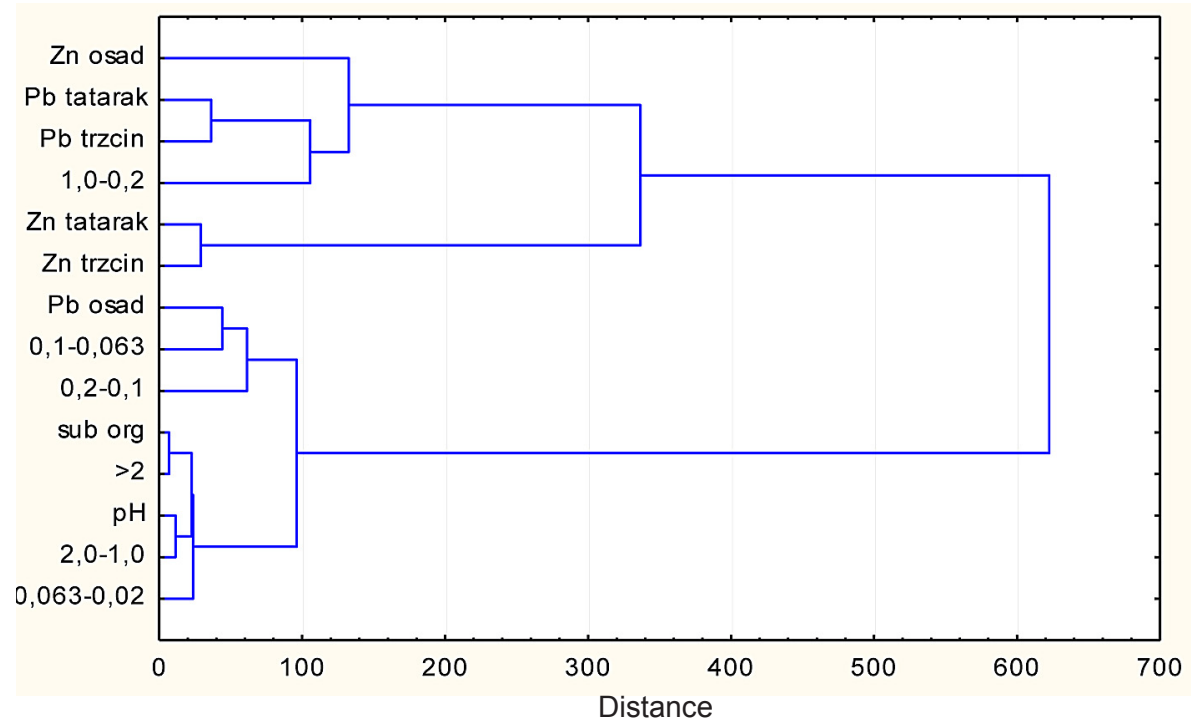

Figure 7. Ward cluster analysis (CA) results from river Narew

\section{CONCLUSIONS}

1. It was proved that zinc and lead in bottom sediments of the river Narew occurred in small amounts except for two measurements points: in Bondary $\left(175.8 \mathrm{mgZn} \cdot \mathrm{kg}^{-1}, 39.8 \mathrm{mgPb} \cdot \mathrm{kg}^{-1}\right)$ and Narew (127.1 mgZn $\left.\cdot \mathrm{kg}^{-1}, 40.5 \mathrm{mgPb} \cdot \mathrm{kg}^{-1}\right)$.

2. The achieved analysis results of plant material indicate a slight exceeding in the case of lead.

3. Zinc and lead concentrations in bottom sediments and plant roots considerably depended on the measurement point. Spatial distribution of these metals contents in the tested plant roots correlates with their contents in sediments. It was proved that aquatic plants are characterized by a greater tendency to accumulate zinc and lead rather than bottom sediments.

4. Sediments particle size and organic matter are factors that affect the zinc and lead contents in bottom sediments also in test plants, which was statistically confirmed.

\section{REFERENCES}

1. Bojakowska I., 2001. Kryteria oceny zanieczyszczenia osadów wodnych. Przegląd Geologiczny 49 (3), 213-218.

2. Bojakowska I., Sokołowska G., 1998. Geochemiczne klasy czystości osadów wodnych. Przegląd Geologiczny 46 (1), 49-54.

3. Demirezen D., Aksoy A., 2004. Accumulation of heavy metals in Typha angustifolia (L.) and Pota- mogeton pectinatus (L.) living in Sultan Marsh (Kayseri, Turkey). Chemosphere 56, 685-696.

4. Dobicki W., 2004. Biodostępność metali ciężkich w środowisku jezior Suwalskiego Parku Krajobrazowego. Wydawnictwo Akademii Rolniczej we Wrocławiu, pp. 99.

5. Du Laing G, Tack fmg, Verloo Mg., 2003. Performance of selected destruction methods for the determination of heavy metals in reed plants (Phragmites australis). Anal Chim Acta, 497, 191-198.

6. Helios-Rybicka E., 1991. Akumulacja i mobilizacja metali ciężkich w osadach środowiska wodnego: osady datowane jako wskaźnik chronologiczny. Konferencja: Geologiczne aspekty ochrony środowiska, Kraków, 18-23.

7. Hu J., Zheng A., Pei D., Shi G., 2010. Bioaccumulation and chemical forms of cadmium, copper and lead in aquatic plants. Brazilian Archives of Biology and Technology Aninternational Journal, 53 (1), 235-240.

8. Jankowski W., 1994. Zastosowanie bioindykacji w praktyce monitoring środowiska na przykładzie północno-wschodniej Polski, Państwowa Inspekcja Ochrony Środowiska, Warszawa.

9. Kabata-Pendias, Pendias, 1999. Biogeochemia pierwiastków śladowych, Wydawnictwo Naukowe PWN, Warszawa.

10. Kolada A., Ciecierska H., 2008. Terenowe metody badania makrofitów $\mathrm{w}$ jeziorach $\mathrm{w}$ świetle monitoringu biologicznego wód zgodnego z Ramową Dyrektywą Wodną, Ochrona Środowiska i Zasobow Naturalnych, 37, 9-23.

11. Landrum P., Harkey G., Kukkonen J., 1996. Evaluation of organic contaminant exposure in aquatic organisms: The significance of bioconcentration adn bioaccumulation. [In:] Newman M.C., Jagoe C.H. 
(eds.) "Ecotoxicology. A hierarchical treatment", CRC/ Lewis Publishers, Nowy Jork, 85-131.

12. Lin CH., He M., Zhou Y., Guo W., Yang Z., 2008. Distribution and contamination assessment of heavy metals in sediment of the Second Songhua River, China, Environ Monit. Assess., 137, 329-342

13. Lis J., Pasieczna A., 1995. Atlas geochemiczny Polski w skali 1: 2500 000, Państw. Inst. Geol., Warszawa, pp. 72.

14. Mazej Z., Germ, M., 2009. Trace element accumulation and distribution in four aquatic macrophytes. Chemosphere 74, 642-647.

15. Rabajczyk A., Jóźwiak M.A., 2008. Możliwości wykorzystania makrofitów jako bioindykatorów metali ciężkich zdeponowanych w osadach dennych (The possibilities of using macrophytes as bioindicators of heavy metals occuring in sediments). Kieleckie Towarzystwo Naukowe, Monitoring Środowiska Przyrodniczego 9, 19-26.

16. Sadowska U. 2012. Ranga bioindykacji w ekotoksykologii wód, Studia Ecologiae et Bioethicae. UKSW, 10(2), 33-52.

17. Salminen R. (Ed.), 2005. Geochemical atlas of Eu- rope. Part 1 - Background Information, Methodology and Maps.

18. Samecka-Cymerman A., Kempers A.J., 2007. Heavy metals in aquatic macrophytes from two small rivers polluted by urban, agricultural and textile industry sewages SW Poland. Arch. Environ. Contam. Toxicol. 53, 198-206.

19. Saygideger S., Dogan M., 2005. Variation of Lead, Cadmium, Copper, and Zinc in Aquatic Macrophytes from the Seyhan River, Adana, Turkey. Bull. Environ. Contam. Toxicol. 74, 545-551.

20. Skorbiłowicz E. 2014. Assessment of heavy metals contients in bottom sediments of Bug River. Journal of Ecological Engineering 15 (3), 82-89.

21. Skorbiłowicz E. 2012. Studia nad rozmieszczeniem niektórych metali $\mathrm{w}$ środowisku wodnym zlewni górnej Narwi.

22. WIOŚ Białystok. Ocena stanu ekologicznego, potencjału ekologicznego i stanu chemicznego rzek województwa podlaskiego w roku 2011, 2012.

23. Zimny H., 2006. Ekologiczna ocena stanu środowiska. Bioindykacja i biomonitoring. Agencja Reklamowo-Wydawnicza Arkadiusz Grzegorczyk, Warszawa. 